Available online at: http://journals.rsfpress.com/index.php/ijmesh

International Journal of Management, Entrepreneurship, Social Science and Humanities

(IJMESH)

ISSN 2580-0981 (online)

Volume 4 Number 2 (2021): 52-65

\title{
Leadership And Management in Multigenerational Teaching Staff in the New Normal: A Phenomenological Study
}

\author{
Crisanta Gutierres-Atienza \\ Laguna State Polytechnic University (Graduate Student), Philippines
}

\begin{abstract}
This research looked into the various life experiences of school principals in Laguna's Basic Education Department, as well as how they guided a multigenerational teaching staff into the new normal. The hermeneutic qualitative research design was used by the researcher. The testimonials of participants can help leaders capitalize on generational differences and use them to create a pleasant work environment. As a result, it became more important for school leaders to have an understanding of what motivates each generation to contribute effectively to the school in the new normal. Researchers looked at each generational group and their differences in order to determine what motivates each generation to contribute effectively to the school in the new normal. Together as One, Heart to Heart Talk, Work from Home, Better Together, Leading the New Way, Silver Lining, The Generational Divide, An Uphill Climb, A Leader, A Fighter, Peaks and Valleys, e-Support, Leadership that Works, and A Competitive Advantage are some of the study's emerging themes. The report included a compendium of best leadership strategies for multigenerational teaching staff in the new normal.
\end{abstract}

Keywords: Hermeneutic, Leadership, Multigenerational, New Normal, Phenomenological

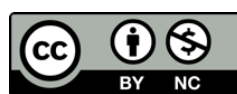

This is an open access article under the CC-BY-NC license.

\section{INTRODUCTION}

In the new normal, a school leader must have the fundamental skills for running a school because they are the most important person in the school because they lead and guide teachers, students, and stakeholders to achieve their goals, vision, and mission. These school leaders in the new normal must be virtual leaders who can successfully respond to the new normal and keep up with the constant changes it brings.

As a result, many school leaders who learned crucial leadership qualities had to deal with generational gaps at work. In the former system, school leaders were dominated by four generations, each of which had its own set of views, perceptions, and beliefs, as well as varied working styles that reflected the generations they were trying to manage. Because they have unique talents and abilities that can boost the workforce's diversity and worth, these leaders should look for the commonality in order to form a functioning team. The duty of the leader is to understand each generation in order to create a work environment that inspires, motivates and is healthy and productive while remaining true to the company's core values. Despite the job description's overwhelming nature, it indicates that the sector has come to recognize the important role of school leaders and their rising expectations (Darling-Hammond, 2015). It has been said numerous times that the duty of the school principal is multifaceted. As a result, strong leadership will produce leadership capabilities. It makes a significant contribution to student learning improvement by influencing the climate and settings in which teaching and learning take place. 
International Journal of Management, Entrepreneurship, Social Science and Humanities (IJMESH), Vol. 4 (2), 52-65 Leadership And Management in Multigenerational Teaching Staff in the New Normal: A Phenomenological Study

Crisanta Gutierres-Atienza

The Path-Goal Theory, which was used in this study, was developed by Robert J. House. This theory holds that people (leaders) are adaptable and can change their style depending on the situation. As Northouse (2013) describes, this strategy focuses on building a leader's style or conduct that best matches the individual and work environment in order to achieve a goal. The goal is to increase teachers' motivation, empowerment, and satisfaction in order for them to become more successful team members. The Path-Goal Theory is a way through which leaders select behaviors that are most suited to the demands of teachers as they move through their daily job tasks or goals. According to Pierce and Newstrom (2011), a leader's behavior is influenced by the contentment, motivation, and performance of his or her followers. Its main focus is on how a leader influences subordinates' perspectives of their professional goals, personal ambitions, and paths to reaching those objectives.

Furthermore, a school leader must be effective in order to cope with some changes and challenges, and in order to be effective, he must consider the importance of behavior in adjusting and embracing the changes and challenges of the school's multigenerational teaching staff in these times of the new normal. Certain roles and obligations necessitate that the administrator's behavior is more human-relationship centered than task-oriented.

To date, in order to remain competitive in these times of the new normal, school leaders must build new learnings that fit the current trend while maintaining what was established in the old normal. If the existing state of one's school's prosperity is taken for granted, it may have an impact on the entire academic institution. As the educational paradigm shifts, it is up to school leaders to create a successful multi-generational workplace and, in the process, learn to appreciate each generation's strengths and opportunities in the new normal.

As a result, many school leaders with critical leadership skills are now challenged with generational differences that can be managed and coordinated by creating a cooperative and collaborative workplace that encourages communication and overall organizational success. Organizations without leaders, according to Cekada (2012), would struggle to achieve the greatest results if they lack the skills or knowledge to develop bridges across generational cohorts. School leaders in the previous system were dominated by four generations, each with its own set of values, perceptions, and beliefs, as well as a variety of working styles that represented the generations they were trying to manage. In order to build cohesive teams, they sought commonality. Each generation contributes a unique set of characteristics and skills to the workplace, which can assist in diversifying and adding value. The duty of the leader is to understand each generation in order to create a work environment that inspires, motivates and is healthy and productive while remaining true to the company's core values.

The pressure is intense, and the solutions are limited for school leaders overseeing a multigenerational teaching staff in these demanding and chaotic circumstances in the new normal. Important periods for building social relationships and exhibiting leadership are no longer available. Parents, kids, and teachers are all living in a twilight world of education, yearning for a new normal that will bring stability, continuity, and reassurance.

The primary goal of this phenomenological study is to investigate the lived experiences of school leaders dealing with multigenerational teaching staff in the new normal. This study specifically addressed the following central and corollary questions: "What is the substance of school leaders' 
International Journal of Management, Entrepreneurship, Social Science and Humanities (IJMESH), Vol. 4 (2), 52-65 Leadership and Management in Multigenerational Teaching Staff in the New Normal: A Phenomenological Study

Crisanta Gutierres-Atienza

lived experiences in dealing with multigenerational teaching staff in the new normal?" as well as the questions that follow (1) In the new normal, how do school administrators describe their experiences with multigenerational teaching staff? (2) What themes arose from the school leaders' testimonies? (3) What compendium of best practices for school leaders who are leading multigenerational teaching staff can be proposed based on the study's findings?

\section{LITERATURE REVIEW}

The findings of other studies are similar and dissimilar to the current study. They provide enough foundation for the researcher to understand how school leaders lead a multigenerational working workforce in these times of the new normal. According to the research of Luistro (2010), Gordon (2010), and Milion (2010), the school leader should be aware of the humanist concepts that best suit them in their interactions with teachers. Young (2005), Andrew (2011), Mclaughin (2016), McDunnigan (2011), and Crawford all agreed that a good leader must assist unite or overcoming disagreements that threaten to break an organization apart in order to be successful. Furthermore, the research conducted by Andrew (2011), Silver (2009), Bradley (2011), Rakiz and Sawnsen (2015), Weiss (2017), Hess (2017), and Abad (2011) provides valuable information about school leaders' attitudes toward nurturing traditions that already express and reinforce positive school culture.

Meanwhile, according to Katz (2012) and Peretomode (2012), as well as Babatunde (2014), conceptual skill helps a leader to think through concepts, abstract and theorize on hypothetical scenarios, as well as make discoveries, strategize via long and short term plans, and put them into action. Furthermore, Okeke (2017), Kowalski (2011), Patrinos (2010), Epino (2010), and Sergiovanni (2010) provided a deeper understanding of how effective coordination of the various aspects of the organization is dependent on school leaders' conceptual skills and the implications for the organization's future direction and cultural tone.

Furthermore, Arnett (2010) and Peterson (2016) stressed in their studies the need for school leaders at all levels to take care of the human side of the teaching staff, while Zachariah (2011), Hand and Prain (2013), McNeely (2015), Edmonson (2018), Johnson (2015), Bell (2011) McLeod (2011), Goodwin (2013) and Anonas (2011) New technologies are highlighted as contributing to a learning environment that is more responsive to the requirements and interests of individual students.

Serhan Henderson, James, and Cannon (2013) and Bailey (2000), on the other hand, focused on the challenges that school leaders encountered in incorporating technology in the classroom, particularly the apprehension that older leaders have of new professional technology learning.

Cakir and Yildirim (2011), Goktas (2011), Haughey (2006), and Duncan (2011) conducted studies to evaluate how engaged and involved private school administrators are with technology. Around technology challenges in private schools, there is a comparison of responses reporting the most leadership involvement to those reporting the least leadership involvement. This is supported by the studies of Creighton (2013), Slowinski (2013), Donovan (2011), Nacrel (2011), and Russell (2014) as they discussed how a school leader could encourage appropriate and effective use of technology. 
International Journal of Management, Entrepreneurship, Social Science and Humanities (IJMESH), Vol. 4 (2), 52-65 Leadership And Management in Multigenerational Teaching Staff in the New Normal: A Phenomenological Study

Crisanta Gutierres-Atienza

In the meantime, Smith (2013) and Anonas (2018) both propose that school administrators should deliberately select and apply the method that will give the essential information while keeping stakeholders focused on the school's purpose, vision, and goals.

Furthermore, Hannay and Fretwell (2011), Meria (2010), Zemke (2000), Broom (2010), Hahn (2011), Ballone (2007), Kaye, Scheff, and Thiefoldt (2003), and Crickenberger (2011) found that the twenty-first-century workplace is undergoing many changes as a result of economic shifts, emerging technology, and workforce composition.

Azorin, Harris, and Jones (2020), Leithwood (2020), Hargreaves (2020), and Taylor (2020) all stated that good school leadership is now linked, collaborative, creative, and responsive as research on leadership in the new normal was discussed.

The aforementioned research is thought to be supportive of emerging themes and analyses of school leaders' lived experiences in dealing with multigenerational teaching staff in the new normal.

\section{RESEARCH METHOD}

The qualitative research approach used in this study was phenomenology. In hermeneutical phenomenology, both interpretation and description of the lived experience are significant. "It is a descriptive (phenomenological) methodology because it is concerned with how things seem and wishes to let things speak for themselves; it is an interpretative (hermeneutic) methodology because it asserts that there are no uninterpreted phenomena." Van Manen is a Dutch actor (Van Manen, 1994). Rather than living out other experiences, he claims that the goal of hermeneutic phenomenology is to recognize and grasp the possibilities of living another's experience. Those possibilities emerge from the process of understanding a text. The text is interpreted using a hermeneutic circle. The hermeneutic circle is used by the researcher to understand the phenomenon.

The "researcher traveling from sections of the experience, to the complete experience, and back and forth again and again to raise the depth and level of knowledge from inside the text" is part of this approach (Laverty, 2003). The participants will tell their stories, and the researcher will analyze them while reflecting on her own personal experiences to acquire a deeper understanding of the occurrence in her own setting. This comprehension process proceeds through multiple cycles before reaching a thorough and in-depth understanding of the phenomenon. The purpose of the reading and re-reading of the texts is to identify themes. The topics detected in each text are searched across all texts to find similar themes. These related themes are either interpreted and shared by a group of researchers, or they are entered into qualitative software to uncover areas of uncertainty. The texts are re-examined, and new definitions and clarifications of themes are added. The researchers will continue to study and re-examine the texts in order to identify any emerging trends. The found patterns should appear in all texts and help the researcher gain a better knowledge of the subject. The hermeneutical cycle should not be viewed as a procedure with fixed steps, according to researchers. It's supposed to be fluid, with no defined number of phases, and analysis continued until no new themes emerge, a process called saturation. 
International Journal of Management, Entrepreneurship, Social Science and Humanities (IJMESH), Vol. 4 (2), 52-65 Leadership and Management in Multigenerational Teaching Staff in the New Normal: A Phenomenological Study

Crisanta Gutierres-Atienza

With this in mind, the researcher examined the lived experiences of school leaders who are dealing with multigenerational working staff in the new normal and reflected on the problems they face. It encourages the researcher to use this research design to look at the anthology of difficulties and competencies that school leaders have acquired.

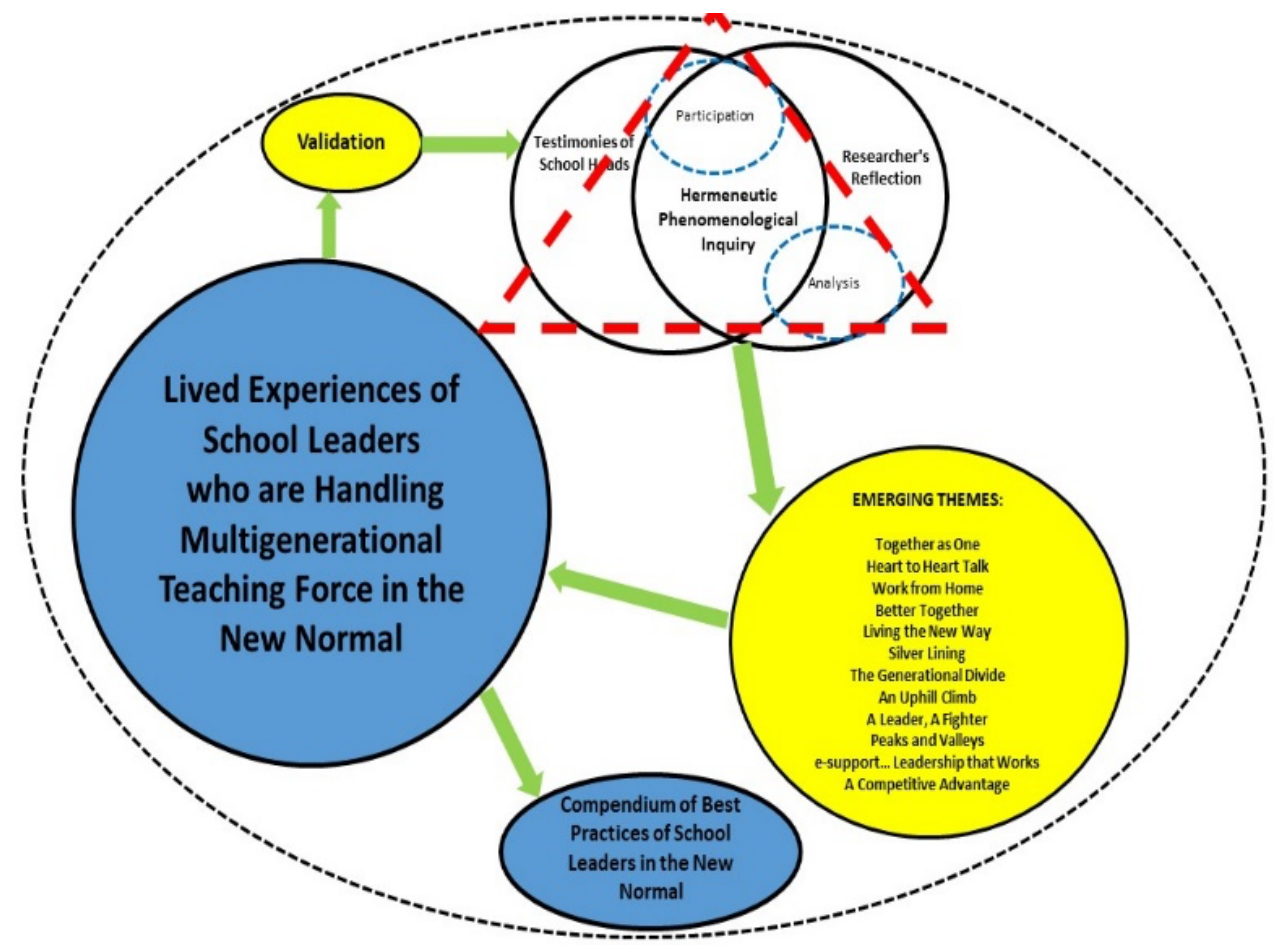

Figure 1. Research Framework

The above framework showed the macro-circle of the interrelation of how the lived experiences of school leaders handling multigenerational teaching forces in the new normal through Hermeneutic Phenomenological Inquiry and the means of methodological triangulation as manifested in broken triangular lines; the above framework showed the macro-circle of the interrelation of how the lived experiences of school leaders handling multigenerational teaching forces in the new normal through Hermeneutic Phenomenological Inquiry and the means of methodological triangulation. To explain how methodological triangulation was employed in this qualitative study, methodological triangulation entails analyzing a phenomenon using many methods. It is important in providing confirmation of findings, more extensive data, increased validity, and a better understanding of the phenomena under investigation by gathering data such as interviews, observations, questionnaires, and documents. In the aforementioned paradigm, methodological triangulation was viewed as a technique for validating validity through the convergence of data from multiple sources, as represented by the arrows representing the order of analysis and the broken circle indicating the process' links. In this scenario, validation was essential, and the researcher's participation, as well as the participants' viewpoints, were reviewed.

The study framework depicts the full process of extracting themes from the responses of participants. Based on the data gathered from the responses, the researcher clustered the material and established the emergent themes. In-depth interviews with the study's participants were used 
International Journal of Management, Entrepreneurship, Social Science and Humanities (IJMESH), Vol. 4 (2), 52-65 Leadership And Management in Multigenerational Teaching Staff in the New Normal: A Phenomenological Study

Crisanta Gutierres-Atienza

to collect the data. Audio, video and field notes were used to record the participants' shared lived experiences using Zoom. The participants were interviewed in order to gain a better understanding of their experiences as school leaders in the new normal, which includes coping with multigenerational teaching staff. The attendees also discussed their personal experiences dealing with multigenerational teaching staff and the challenges of leadership in these new normal times. In addition, the participants discussed their experiences dealing with multigenerational teaching staff in the new normal.

Similarly, the researcher gathered all of the information from the interviews and verbatim transcribed all twelve (12) participants' interviews. The exemplars from the transcription were then sorted into themes and clusters by the researcher. Finally, the responses of the participants were used to extract the emerging themes. As a research methodology, qualitative research methodology adds to the exploratory ability that researchers need to evaluate and investigate their research topics. Researchers can develop and apply qualitative techniques to their exploratory research procedures to improve and utilize their interpersonal and subjectivity talents. The benefits of a study that employs an interpretative phenomenological analysis (IPA) technique, on the other hand, treble since the method helps researchers to form a bond with their research participants.

A non-probability purposive sampling design was adopted in the investigation. Participants who satisfied the eligibility criteria were contacted, the study's purpose was explained to them, and they agreed to take part. The researchers chose the participants and provided clear and exact information regarding the problems faced by school leaders directing multigenerational teaching staff in the new normal. According to Clemente, Julaton, and Orleans (2016), The sample size was decided by information saturation, which refers to the moment at which previously collected data was verified once more. Rather than using sample methodologies to provide broad data, the design was chosen because the research resulted in a thorough or rich account of teaching experiences. Containing a specific goal in mind, cases with a lot of information for in-depth analysis were developed. Pre-interviews were also conducted by the researcher in order to choose the study's participants. The purpose of the initial interview was to see if potential volunteers were willing and open to taking part in the study.

Twelve (12) chosen school leaders who manage multigenerational teaching personnel in selected private schools in Laguna took part in the study. In the new normal, it is these leaders who are dealing with multigenerational teaching staff. The participants were chosen by the researcher because they gave clear and tangible information about the issues faced by school leaders guiding multigenerational teaching staff in the new normal.

\section{FINDINGS AND DISCUSSION}

The study's participants are all school principals from various Laguna schools. The testimonials of these school leaders demonstrate how, even in this era of the new normal, nearly every school in Laguna has three or more generations working together. The ability of school principals to lead their teaching staff may be harmed as a result of this. These principals, who supervise teachers from multiple generations, must be aware of each cohort's orientation in order to avoid conflicts and offer good job outputs, whether in person or remotely. 
International Journal of Management, Entrepreneurship, Social Science and Humanities (IJMESH), Vol. 4 (2), 52-65 Leadership and Management in Multigenerational Teaching Staff in the New Normal: A Phenomenological Study

Crisanta Gutierres-Atienza

School leaders can use the themes found in this research study to guide their efforts in learning more about the challenges of leading multigenerational teaching staff in the new normal and implementing effective solutions to boost multigenerational teachers' motivation and productivity.

\section{What themes emerged from the testimonies shared by the school leaders who are multigenerational teaching staff in the new normal?}

\section{Together as One}

Collaborative Learning Theory, which is based on Lev Vygotsky's (1896 - 1934) theory of Zone of Proximal Development, backed up the emerging theme. Learners here rely on one another to do things that they would not be able to finish on their own. Collaborative learning is essential for the development of critical thinking skills, with research indicating that students remember more material when they work in groups. It entails peer-to-peer learning, which encourages students to think more deeply in the classroom. The researcher's argument is backed up by a study by Wen (2010), which found that teamwork is essential for innovation that entails accomplishing more with less.

A greater sense of togetherness in the school can be established by creating the expectation that a school leader wants to see regular collaboration and providing numerous routes for doing so. While it may appear that bridging generational divides in the classroom is challenging, this will assist in the formation of a thriving team that utilizes each team member's knowledge and viewpoint to jointly and effectively address your company's challenges and opportunities. This theme can assist school leaders in discarding prejudices and embracing open communication, individualism, and collaboration in order to guide the multigenerational workforce to work well together and achieve personal and school goals.

\section{Heart to Heart Talk}

Salako (2016) found that understanding, education, empowerment, and respect are the best qualities of good communication in school, which he described in his study. This gives folks the information they need to educate and enlighten themselves. When individuals know what's going on, they feel respected and empowered, and they're more inspired to work at their best. Communication is the "lifeblood" of each school leader and is essential to their success. Successful communication has two benefits: rich connections and the ability to correctly and completely communicate thoughts, feelings, and ideas. Effective communication is the foundation of any successful endeavor, especially when it is communicated from the heart. This subject can influence a leader to exercise empathy and transparency, as well as comprehend how these teachers perceive things. This theme can also influence a leader to improve communication skills and become a better school leader by working from home or online.

\section{Work from Home}

Lupu (2017) supports this conclusion and assertion, stating that "out of sight, out of mind" is true for teachers who work from home when it comes to promotions. According to his research, coteachers who stay at the school have a better chance of being noticed and getting promoted sooner because the administration is unaware of the interpersonal communication skills and relationships of the homeschooling teachers. This circumstance has an impact on his or her future performance since the current principal has concerns about making suggestions because he or she does not have a clear picture of the instructor working from home. Working from home has the disadvantage of 
International Journal of Management, Entrepreneurship, Social Science and Humanities (IJMESH), Vol. 4 (2), 52-65 Leadership And Management in Multigenerational Teaching Staff in the New Normal: A Phenomenological Study

Crisanta Gutierres-Atienza

denying teachers the ability to maintain an informal communication network with their coworkers. When teachers don't have these contacts, they may feel disconnected from their colleagues as well as the school's aims and ideals.

Academic leaders must have a clear view of the future and how WFH may best serve their institution. Surviving the current situation isn't a goal in and of itself. Beyond the pandemic, school leaders must comprehend why remote working is necessary. WFH merely requires leaders to focus on the essentials of excellent leadership, such as setting clear goals, conducting effective meetings, communicating effectively, and using teachers' individual and collective abilities.

\section{Better Together}

The fourth topic that arose was Collaborative Learning Theory, which is a notion that establishes a theoretical and research field with a distinctive identity. Although there is a long history of research in the fields of psychology and education on the topic of intellectual cooperation (Melero Zabal \& Fernández Berrocal, 1995; Roselli, 1999a; Rodriguez Barreiro, Fernández, Escudero \& Sabirón, 2000; Barkley, Croos \& Major, 2007; Strijbos \& Fischer, 2007), the idea of working in a group or team is commonly linked with the 1980s, but it is only in the 1990s that the idea gets a fresh push, giving rise to the epistemic discipline known as collaborative learning. Instead, collaboration would be a collaborative process from the start, with all of them working together to complete the assignment. This is not to say that natural role distinction is impossible, but rather those interacting dynamics occur spontaneously.

Transparency, honesty, integrity, reliability, responsibility, and educators' commitment to shared goals are all required for collaboration with principals and teachers. A school that supports collaboration must be developed and supported by the administration for long-term success. It's also a prerequisite for teachers to develop in their professions and accept and implement change in the new normal efficiently.

\section{Leading the Way}

All school leaders will be involved in crisis and change management on a regular basis, which will demand the cooperation and support of the entire staff. The establishment of a new leadership order with no leadership criterion has occurred. This method of leadership is based on the mobilization of others to lead through collective involvement and action rather than on command and control (Azorin, 2020). Distributed leadership shifts the focus away from individual leaders' actions and toward their relationships with others, resulting in shared engagement and practice. School leaders are currently focusing their substantial leadership energies on engaging people in collaborative, shared, and collective work that is necessary for the school.

In order to lead in stormy times, you must be able to design a new course and develop new avenues amid the chaos. On this route, school leaders are marked by their persistence, hope, and unflinching belief that, whatever happens, whatever the cost, whatever the magnitude of the challenge, they would do everything in their power to guarantee that all teaching staff is led and learn in the new normal.

\section{Silver Lining}

This emerging theme was bolstered by Transformational Leadership, a term first articulated by McGregor Burns in his book "Leadership" in 1978. He characterized transformational leadership as a process in which leaders and their followers boost one another's morality and motivation to new heights. This type of leader, according to his 1985 book "Leadership and Performance Beyond 
International Journal of Management, Entrepreneurship, Social Science and Humanities (IJMESH), Vol. 4 (2), 52-65 Leadership and Management in Multigenerational Teaching Staff in the New Normal: A Phenomenological Study

Crisanta Gutierres-Atienza

Expectations," "sets clear goals, has high expectations, encourages others, provides support and recognition, stirs people's emotions, gets people to look beyond their self-interest, and inspires people to reach for the improbable "The administrator should ensure that teachers from various generations see the light at the end of the tunnel, acknowledging both the good and the bad, as well as the lessons gained and the future growth." This also means that good school leaders display "deliberate calm and bounded optimism" in times of crisis, indicating that they are confident in their ability to overcome any challenge, despite the uncertainty about when and how the crisis will end. Leaders with limited optimism, on the other hand, may be able to achieve a balance between being confident in their ability to solve problems and not making promises they can't keep.

\section{The Generational Divide}

Generational disparities are frequently cited as a source of tension. There are obvious differences between younger and older teachers in terms of how they dress, what music they enjoy, how they use technology, and how they interact. People who are decades apart in age sometimes find that their attitudes toward work and appropriate behavior change with time - sometimes as a result of the era in which they grew up, but also as a result of their different life phases and professional stages.

Mannheim's Theory of Generations backs up this notion (1923). Mannheim tends to see social location as a generational element that might explain varied actions and methods attributed to different generations, as Pilcher (1994) points out. According to Mannheim, biological causes alone cannot account for the historical and generational changes that characterize each generation; rather, social and cultural variables may plausibly justify the occurrence of particular features throughout generations.

The term "generational difference" is frequently used to refer to a variety of differences. To be successful, school leaders must be able to deal with all of these issues while avoiding generational stereotypes that draw attention away from the root causes of conflict.

\section{An Uphill Climb}

The eighth theme that arose from the participants' testimony is about the leadership challenges that develop in the new normal when dealing with a multigenerational teaching staff, which can be linked to the tough process that the school principal goes through while leading in the new normal. Fiedler's (1978) contingency model of leadership effectiveness, as well as Tokin's transformational leadership conceptions, backed up the emerging idea (2013). In order to achieve effective leadership, Fiedler and Tokin's theories rely on interactions between leadership styles and situational favorableness. Some empirically validated theories of leadership effectiveness, according to Fiedler (1978), reveal intricate relationships between leader qualities, leader conduct, and environmental influence.

Because of the unpredictability that school leaders experience when managing a multigenerational teaching staff in the new normal, they must be able to adapt quickly to changing conditions and draw on a diverse set of skills and leadership styles. To be effective as a leader, you must be able to change and adapt your leadership style according to the situation. In the new normal, school leaders 
International Journal of Management, Entrepreneurship, Social Science and Humanities (IJMESH), Vol. 4 (2), 52-65 Leadership And Management in Multigenerational Teaching Staff in the New Normal: A Phenomenological Study

Crisanta Gutierres-Atienza

just need to pick the correct tool for dealing with multigenerational teaching staff because they have a variety of tools at their disposal. Effective school leaders acknowledge and respond to the different contextual demands that they face in the current education crisis caused by the pandemic.

\section{A Leader, A Fighter}

The New Normal Leadership, as defined by Francisco (2020), is a good leader who learns to do ordinary things well, is not hesitant to act even when challenged, and is not scared to take on the impossible. In his research, he discovered. According to his research, schools are witnessing a new normal leadership because they are facing tough circumstances with much stronger demands for accountability and limited financial resources.

Today's school leaders are dealing with a slew of leadership issues brought on by the pandemic. The true test of a school leader is how they display emotional strength, chutzpah, and professionalism at the hardest moments, not how they perform during the good times. Fighting school leaders who are leading a multigenerational teaching staff in the new normal focus their efforts on their "circle of influence," which consists of everything they can influence. They focus their time and energy on things they can control rather than reacting to or becoming irritated about situations over which they have little or no control.

\section{Peaks and Valleys}

In the new normal, the behavior and preferred technologies of the multigenerational teaching staff combine to create a technological generation gap, in which teachers from different generations demonstrate varying levels of ability and willingness to adopt new technology, shaped by their personal experiences.

The findings and assertions are closely related to Knowles' (1980) Adult Learning Theory, which relates to adult learning, generations, and technology in the workplace. He coined the term "andragogy," which he defined as "the art and science of assisting adults in learning." Andragogy was founded on a four-assumption knowledge base, with two more assumptions added subsequently. Schools in the new normal are made up of intergenerational teaching staff, so they will continue to face changes and problems, but the good news is that they can prepare for and respond to them in advance. Workforce changes have an impact on school organizations. Teachers from each generation should be considered when making decisions about how to deliver technology-based instruction.

\section{e-Support, Leadership that Works}

Avolio and Kahai (2003) looked at how technology affects leadership in organizations by defining e-leadership and investigating how it affects leaders, followers, teams, and organizations. Eleadership, according to the authors, is more than just an extension of traditional leadership; it is a fundamental shift in the way leaders and followers interact within and across organizations. Even in this changing setting, the authors emphasized that some leadership fundamentals will almost certainly remain the same. The authors wrapped up their paper with several takeaways from their e-leadership research. The authors characterize e-leadership as a "silent revolution" that resulted in the wiring of businesses to the point where many critical human interactions are now mediated by information technology. They defined leadership as a dynamic, dependable system operating inside a larger organizational system. They went on to say that well-defined organizational structures establish the kind of interactions that can be expected among employees. 
International Journal of Management, Entrepreneurship, Social Science and Humanities (IJMESH), Vol. 4 (2), 52-65 Leadership and Management in Multigenerational Teaching Staff in the New Normal: A Phenomenological Study

Crisanta Gutierres-Atienza

Leaders can now oversee complete projects from afar and communicate with followers or team members purely through technology. E-leadership takes shape in a virtual environment where cooperation and leader-follower interaction are mediated, with the goal of creating and disseminating organizational vision, gluing organizations or individuals together, and directing and supervising plan execution. E-leadership, like traditional face-to-face leadership, maybe inspiring by communicating pride in the accomplishments of various teams by e-mail or other electronic means, which is reinforced periodically by stories published electronically throughout the organization. The authors stated that they are fairly certain that information technology-mediated leadership can exhibit the same content and style as traditional face-to-face leadership.

\section{A Competitive Advantage}

The result can be anchored in the transforming Leadership Theory Burns (1978), which observed leaders and found them to be self-centered and lacking in remarkable abilities. This sparked the development of the changing leadership idea. Leadership, according to Burns, should not be about having or wielding power for the sake of it but rather about using power to bring constructive change to the organization and its people. That, according to Burns, is the distinction between a power holder and a transformative leader. According to Burns (1978), transformative leaders have high levels of energy, enthusiasm, and passion for their values and the purpose and vision they want to achieve. Transforming leaders are genuine and charismatic, build pride in their followers, and motivate them to act in ways that benefit the team (Bass, 1990; Burns, 1978).

Transforming leaders are able to successfully engage each cohort, take advantage of generational variety, and foster a culture of unity and productivity. In a meta-analysis of leader influence on subordinate behavior, Chiaburu, Smith, Wang, and Zimmerman (2014) found that transformational leaders are the key to assuring positive follower behavior and, as a result, organizational success. The changing leadership theory of Burns (1978), which focused on recognizing the competitive advantage of leading a multigenerational workforce, was pertinent to this study.

Younger people who grew up during the Digital Revolution have had more exposure to digitalization and innovation, and as a result, are more open to adopting new technologies and agile working methods. Experienced teachers, on the other hand, can help steer the younger generation's ideas to reach practical business goals by sharing their expert knowledge and industry experience. Teams are enabled to co-create initiatives that blend prior learnings with fresh innovation for increased efficiency by fostering such open collaboration. Schools that tap into each generation's diverse knowledge, ideas, and individual abilities will have a distinct advantage in developing a future-ready workforce.

\section{CONCLUSION}

Particularly, this study answered the researcher's central and corollary questions. The following are the conclusions stipulated in the study:

1. School administrators must cultivate and encourage effective communication among intergenerational teaching staff members as well as between school leaders and instructors. The researcher also discovered that good communication skills and constructive criticism were the most effective tactics for a school leader's success in the classroom. 
International Journal of Management, Entrepreneurship, Social Science and Humanities (IJMESH), Vol. 4 (2), 52-65 Leadership And Management in Multigenerational Teaching Staff in the New Normal: A Phenomenological Study

Crisanta Gutierres-Atienza

2. School administrators can use the themes revealed in this research study to help them obtain a better understanding of the challenges of leading multigenerational teaching staff in the new normal and to develop effective measures to boost multigenerational teachers' enthusiasm and productivity. The findings of this study back up and confirm what the researcher has found in previous and current research: managing the variety of a multigenerational teaching staff efficiently is critical to the success of most schools in the new normal.

3. The researcher develops a compendium of best practices for school leaders who are leading multigenerational teaching staff as a result of the study in order to gain a glimpse of how principals overcome the challenges of leading in the new normal and to effectively perform their functions and responsibilities as school leaders who lead teachers from four generations in the new normal.

\section{Limitation \& Further Research}

School leaders can use the themes found in this research study to guide their efforts in learning more about the challenges of leading multigenerational teaching staff in the new normal and implementing effective solutions to boost multigenerational teachers' motivation and productivity. The following suggestions are based on developing themes from participant replies, a literature review, and conceptual frameworks.

1. All school leaders may receive training on leading multigenerational teaching staff in the new normal from the school leaders.

2. Internal policies and programs based on a comprehensive understanding of the teachers' traits and needs may be developed by school leaders to build a deeper sense of belonging, respect for other generations, and knowledge-sharing.

3. School administrators may make an effort to recognize and comprehend the talents and competencies of each generation.

4. In the new normal, school administrators may view multigenerational workplaces as a challenging problem to handle and may take aggressive measures to address them.

5. Future scholars may conduct additional studies to study areas not included in this work in order to overcome limitations and delimitations.

\section{REFERENCES}

Abad, M. (2011). Supervision and instruction: The Philippine Perspective. Malate, Manila, Philippines: De La Salle University Press.

Armstrong, M. (2004). Human Resource Management Theory and Practice. London: Bath Press Ltd. Asfor, A. (2014). Strategies for leadership styles for multi-generational workforce. Journal of Leadership, Accountability and Ethics; Lighthouse Point, 11(2), 58-69.

André, S. (2018). Embracing generational diversity: Reducing and managing workplace conflict. ORNAC Journal, 36(4), 13-35.

Azorin, T. (2020). The new normal education. Retrieved from https://www.researchgate.net/publication/341981898 through the Lens of Education in the Philippines. The New Normal

Ballone, C. (2017). Consulting your clients to leverage the multigenerational workforce. Journal of Practical Consulting, 2, 9-15. 
International Journal of Management, Entrepreneurship, Social Science and Humanities (IJMESH), Vol. 4 (2), 52-65 Leadership and Management in Multigenerational Teaching Staff in the New Normal: A Phenomenological Study

Crisanta Gutierres-Atienza

Barenechea, N. (2013). It's not you, it's me: Transformational leadership and selfdeprecating humor. Leadership and Organizational Development Journal, 34, 4-19. doi:10.1108/01437731311289947.

Bennett, J., Pitt, M., \& Price, S. (2012). Understanding the impact of generational issues in the workplace. Facilities, 30(7/8), 278-288. http://dx.doi.org.seu.idm.oclc.org/10.1108/02632771211220086.

Bernik, A. B. (2014). Do intrinsic and extrinsic motivation factors differ for Generation X and Generation Y? International Journal of Business and Social Science, 5, 1221. Retrieved from www.ijbssnet.com.

Bhatt, G.D., (2011). "Knowledge management in organizations: examining the interaction between technologies, techniques, and people", Journal of Knowledge Management, 5 (1), 68-75.

Broom, C. (2010). Entice, engage, endure: Adapting evidence-based retention strategies to a new generation. Journal of Healthcare Leadership, 2, 49.

Cekada, T. L. (2012). Training a multigenerational workforce: Understanding key needs and learning styles. Professional Safety, 57, 40-44. Retrieved from www.asse.org.

Chapin, T. (2017). Trust, leadership style and generational differences at work-A qualitative study of a three-generation workforce from two countries. Nordic Journal of Business, 66(4), 257-276.

Christians, C. G. (2005). Ethics and politics in qualitative research. In N. K. Denzin \& Y. S. Lincoln (Eds.), The Sage handbook of qualitative research (3rd ed., pp. 139-164). Thousand Oaks, CA: Sage.

Clark, K. R. (2017). Managing multiple generations in the workplace. Radiologic Technology, 88(4), 379-398.

Creswell, J.W., \& Plano Clark, V. L. (2011). Designing and conducting phenomenological research ( $2^{\text {nd }}$ ed.). Thousand oaks CA: Sage publication, Inc.

DepEd. (2020). Official Statement Department of Education. Retrieved from https://www.deped.gov.ph/2020/05/06/official-statement-2.

DOH. (2020). Department of Health Philippines. Retrieved from http://www.doh.gov.ph/2019-.

Fraone (2011). Generations at work: Are there differences and do they matter? International Journal of Human Resource Management, 22, 1843-1865. doi:10.1080/09585192.2011.573966

Gerr, R. L. (2014). Sufficient challenges and a weekend ahead - Generation Y describing motivation at work. Journal of Organizational Change Management, 27, 569-582. doi:10.1108/JOCM 05-2014-010

Glickman, C.D., Gordon S.P., \& Ross-Gordon J.M. (2010), Supervision and instructional leadership:A developmental approach, (5 $5^{\text {th }}$ edition) Toronto: Allyn and Bacon.

Growe, R. (2011). Collaborative Leadership in the Era of New Normal. National Forum of Educational Administration and Supervision Journal, 29 (4).

Guba, E. G., \& Lincoln, Y. S. (2005). Paradigmatic controversies, contradictions, and emerging confluences. In N. K. Denzin \& Y. S. Lincoln (Eds.), The Sage handbook of qualitative research (3rd ed., pp. 191-215). Thousand Oaks, CA: Sage

Goodman, K., \& Goodman, Y. (1990). Vygotsky in a whole language perspective. In L. C. Moll (Ed.), Vygotsky and education: Instructional implications of sociohistorical psychology (pp. 223-251). New York, NY: Cambridge University Press.

Hahn, J. (2011). Managing multiple generations: Scenarios from the workplace. Nursing Forum, 36, 119-127. 
International Journal of Management, Entrepreneurship, Social Science and Humanities (IJMESH), Vol. 4 (2), 52-65 Leadership And Management in Multigenerational Teaching Staff in the New Normal: A Phenomenological Study

Crisanta Gutierres-Atienza

Honoré, R. L., Robison, J. (2012). Leadership in the New Normal: A Short Course. Acadian House Publishing, 183.

Johnson, M. (2015). Engaging a multigenerational and multicultural workforce: One style does not suit all. Plans \& Trusts, 33(5), 10-15.

Karalis, T. (2020). Planning and Evaluation during Educational Disruption: Lessons Learned from Pandemic for Treatment and Emergencies in Education. European Journal of Education Studies, 7(4). https://doi.org/10.5281/zenodo.3789022.

Katz, J. (2012). On leadership skills. Day-to-day leadership. International Digest - p.16.

Lincoln, Y. S., \& Guba, E. G. (1985). Naturalistic inquiry. Newbury Park, CA: Sage Publications.

Luistro, A. (2010). A September 26, 2010 press release by the Department of Education. Retrieved from http://www.gov.ph/2010/09/26/deped

Maxwell, J. C. (2007). The 21 irrefutable laws of leadership. Nashville, TN: Thomas Nelson, Inc.

Mazumder, J. (2012). Understanding the impact of generational issues in the workplace. Facilities, 30, 278-288. doi:10.1108/02632771211220086.

McDunnigan, L. (2011). Effective principal leadership behavior: the student perspective. California State University, San Bernardino. Retrieved (November 3, 2017) http://scholarworks.lib.csusb.edu/etd.

McLaughin, E. (2016). Effective leadership for effective urban schools. Education \& Urban Society.

Mc Neely, N. (2015). Shop Talk, Volume 11, No. 4 Retrieved from December 12, 2017 from www.google.

Northouse, P.G. (2007). Leadership: Theory =and Practice. Thousand Oaks: Sage Publications, Inc. Retrieved December 6, 2016 from http://www.regent.edu/acad/global/publications/lao/issu_19.pdf.

Roy, D. (2012). Educational technology leadership for the age of restructuring. The Computing Teacher 19(6), 8-14.

Sergiovanni, T.J. (2010). Leadership for the Schoolhouse, $1^{\text {st }}$ Edition. HB. Printing, California.

Sessa V. I. Kabacoff, R.I., Deal, J., \&Brown, H. (2007). Generational differences in leader values and leadership behaviors. Psychologist-Manager Journal, 10,47-74.

Smith, B. (n.d). Executive book summary entitled Inspirational Leadership. Destiny, calling and cause. Retrieved from http://keithdwalker.ca/wp-content/summaries/g-k/inspirations.pdf.

Smith, J. (2001). Modeling the social construction of knowledge in ELT teacher education. ELT Journal, 55, 221-227.

Stakonsvy, Michael A. (2000). KM World Special Millennial Issue: A Theoretical Framework: KM World.

Toquero, C. M. (2020). Challenges and Opportunities for Higher Education amid Pandemic: The Philippine Context. Pedagogical Research, 5(4). https://doi.org/10.29333/pr/7947.

UNESCO. Migration, Displacement \& Education: Building Bridges, Not Walls. 2019. Available online: https://en.unesco.org/gem- report/report/2019/migration (accessed on 3 June 2020).

World Health Organization. Retrieved from https://www.who. int/docs/default-source/situation reports/20200311 -sitrep-51-covid-19.pdf?sfvrsn=1ba62e57_10.

Young, A. (2005). Best of Educational Leadership 2003-2005 (Abstract) Summer Vol. 61. 